\title{
Granular Cell Ameloblastoma: an Unusual Histological Subtype Report and Review of Literature
}

\author{
Nikolaos G. Nikitakis', Fotios Tzerbos², Kyriaki Triantafyllou', Christos Papadimas², Alexandra \\ Sklavounou ${ }^{1}$ \\ ${ }^{1}$ Department of Oral Pathology and Medicine, School of Dentistry, National and Kapodistrian University of Athens, Greece \\ ${ }^{2}$ Department of Oral and Maxillofacial Surgery, School of Dentistry, National and Kapodistrian University of Athens, Greece
}

\author{
Corresponding Author: \\ Nikolaos G. Nikitakis \\ Department of Oral Pathology and Medicine, \\ School of Dentistry, University of Athens \\ 2 Thivon St., Goudi 11527, Athens \\ Greece \\ Phone: +30 2107461003 \\ Fax: +30 2107461220 \\ E-mail: nnikitakis1@yahoo.com
}

\begin{abstract}
Background: Granular cell ameloblastoma is a rare histological subtype of ameloblastoma accounting for less than 5\% of the total. The characteristic microscopic features of granular cells are attributed to the increased presence of lysosomes in the cytoplasm of the tumour cells.

Methods: A case of bone expansion in the mandible of 65 year old patient was examined on the basis of the clinical examination, radiographic imaging and microscopic features. A complete surgical removal was performed.

Results: The radiographic imaging characteristics were consistent with a locally aggressive jaw lesion. Histological examination of the tumour revealed typical features of granular cell ameloblastoma. The specimen margins were free of tumour and the postoperative course was uneventful. No evidence of recurrence was noticed during a 1.5 years follow-up period.

Conclusions: The rarity of the granular cell ameloblastoma subtype and the possibility of confusion with other odontogenic and non-odontogenic lesions with a granular cell component require an understanding of the salient features of this locally aggressive neoplasm. A literature review is provided focusing on emerging molecular parameters in the pathogenesis of these tumours and the differential diagnosis of oral lesions featuring granular cells.
\end{abstract}

Keywords: jaw neoplasms; ameloblastoma; odontogenic tumor; lysosomes.

Accepted for publication: 29 September 2010

To cite this article:

Nikitakis NG, Tzerbos F, Triantafyllou K, Papadimas C, Sklavounou A. Granular Cell Ameloblastoma: an Unusual Histological Subtype Report and Review of Literature.

J Oral Maxillofac Res 2010 (Oct-Dec);1(4):e3

URL: http://www.ejomr.org/JOMR/archives/2010/4/e3/v1n4e3ht.pdf

doi: $\underline{10.5037 / \text { jomr.2010.1403 }}$ 


\section{INTRODUCTION}

The ameloblastoma is a benign odontogenic tumour located almost exclusively in the jaws. It has a distinctive microscopic appearance characterized by the presence of peripheral columnar cells with hyperchromatic, reversely polarized nuclei, arranged in a palisaded pattern [1]. These cells closely resemble ameloblasts, coining the tumour's name. It has been proved that these cells are epithelial in origin and can express amelogenin, a precursor of enamel $[\underline{2}, \underline{3}]$.

Based on clinicopathologic criteria, ameloblastomas are divided into three fairly distinct types: solid or multicystic (about $86 \%$ of all cases), unicystic (about $13 \%$ of all cases) and peripheral (about $1 \%$ of all cases) [1]. These tumours occur slightly more often between the third to fifth decades of life, with no significant gender or racial predilection; the most common location is the mandible, particularly near the angle [1]. Although benign, solid or multicystic ameloblastomas (and, to a lesser extent, unicystic ameloblastomas) are locally aggressive, with a high recurrence rate after local excision $[\underline{1}, \underline{4}]$.

Ameloblastomas usually manifest as a hard-tissue swellings that may assume very large dimensions if left untreated. Pain and paresthesia are unusual clinical features $[1,5]$. The usual radiographic appearance of solid or multicystic ameloblastomas is a multilocular radiolucency with well-defined borders. A unilocular presentation is also possible for conventional ameloblastomas and is always associated with unicystic ameloblastomas. Expansion or perforation of the cortical bone, as well as resorption or divergence of the roots of the adjacent teeth, are frequent $[1,5]$.

Several microscopic subtypes of the ameloblastoma, especially of its solid/multicystic variant, are recognized, although these microscopic patterns generally have little bearing on the behavior of tumour. Large tumours often show a combination of microscopic patterns. The follicular and plexiform patterns are the most frequent. Less common histopathologic subtypes include the acanthomathous, granular cell, desmoplastic, and basal cell $[\underline{1}, \underline{5}]$. Although the treatment and prognosis are virtually the same (with the possible exception of more aggressive desmoplastic variant), knowledge of various histopathologic subtypes is a prerequisite for accurate diagnosis and management [1].

The granular cell subtype of ameloblastoma is characterized by the groups of granular cells, which have abundant cytoplasm filled with eosinophilic granules that resemble lysosomes, both ultrastructurally and histochemically [1].
The acquisition of granular cell phenotype has been attributed to an aging or degenerative change in longstanding lesions; however, it may also affect young patients. When this granular cell change is extensive in an ameloblastoma, the designation of granular cell ameloblastoma is appropriate [1].

The purpose of this paper is to present an unusual case of granular cell ameloblastoma and to review the pertinent literature highlighting its unique microscopic features that allow its distinction from other jaw tumours with a granular cell constituency and discussing the molecular aspects of its pathogenesis.

\section{CASE DESCRIPTION AND RESULTS}

A 65 years old male presented with a chief complaint of a painless swelling in his mandible. Clinical examination revealed a well-circumscribed bone expansion on the body of left mandible. Panoramic radiograph revealed a large, multilocular radiolucency with ill-defined borders, located in the body of partial edentulous left mandible and extending from the first premolar to the second molar area (Figure 1). Computed dental tomography showed a hypodense lesion causing thinning of the buccal and lingual cortical plates (Figure 2). During surgical exploration, perforation of the buccal cortical plate was noticed (Figure 3). The lesion was completely removed and the surgical specimen, which appeared as a lobulated soft tissue mass (Figure 4), was submitted for the histological examination. Sections of the formalin-fixed paraffin-embedded tissue were stained with the hematoxylin and eosin. The lesion was composed of fibrous stroma with areas of degenerated myxomatous connective tissue, which was widely infiltrated by the nests and islands of tumour cells of apparent odontogenic origin (Figure 5A).

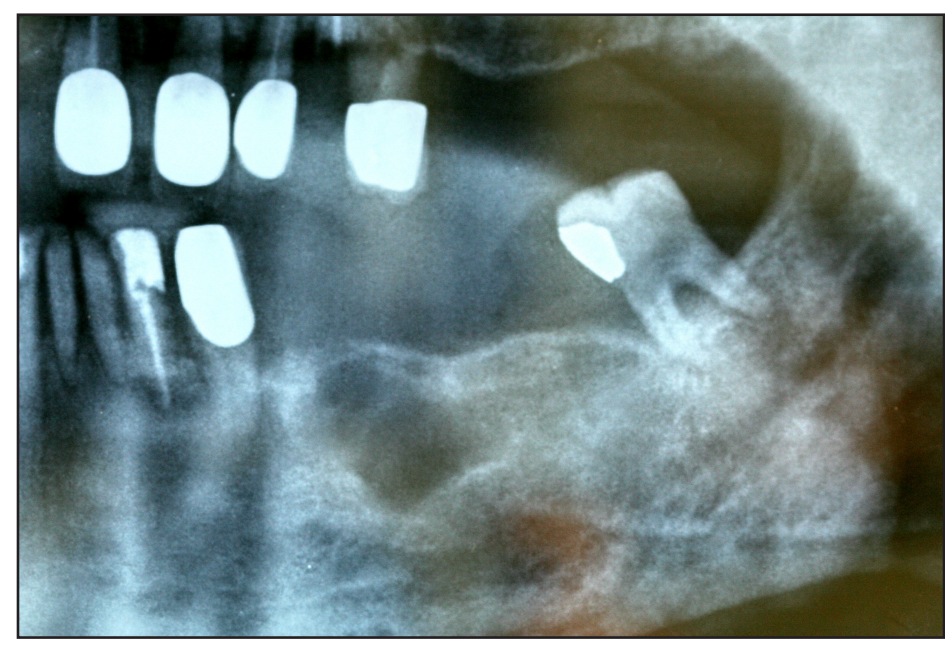

Figure 1. Panoramic radiograph showing large, multilocular radiolucency, located in the left mandible. 
The peripheral layer of tumour aggregates consisted of a parallel arrangement of tall cylindrical cells with reverse polarity of their hyperchromatic nuclei and vacuolization of the cytoplasm. Also, the accumulations of cells rich in eosinophilic granular cytoplasm were found in the central areas of the majority of the tumour islands (Figure 5B). A diagnosis of granular cell ameloblastoma was rendered. The postoperative course was uneventful and no clinical or radiographic signs of the recurrence were noticed at the 1.5 year followup appointment.

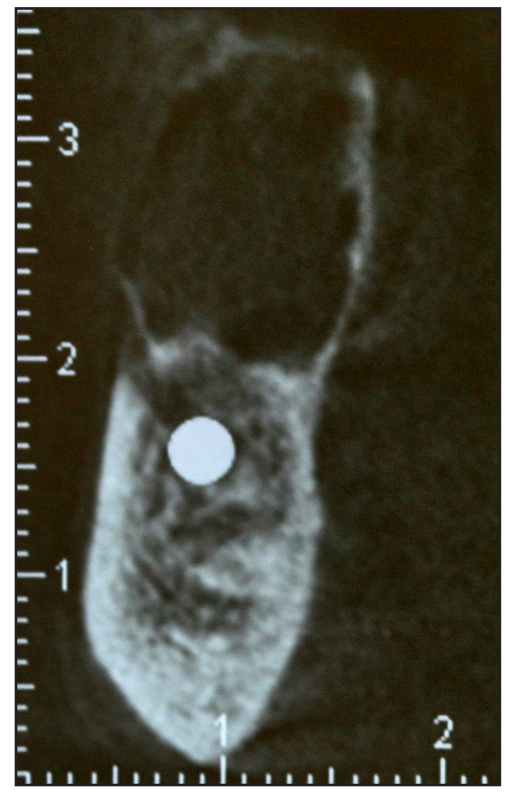

Figure 2. Computed tomography showing a hypodense lesion with aggressive imaging features: it thinned bone margins both on the buccal and lingual sides of the mandible.

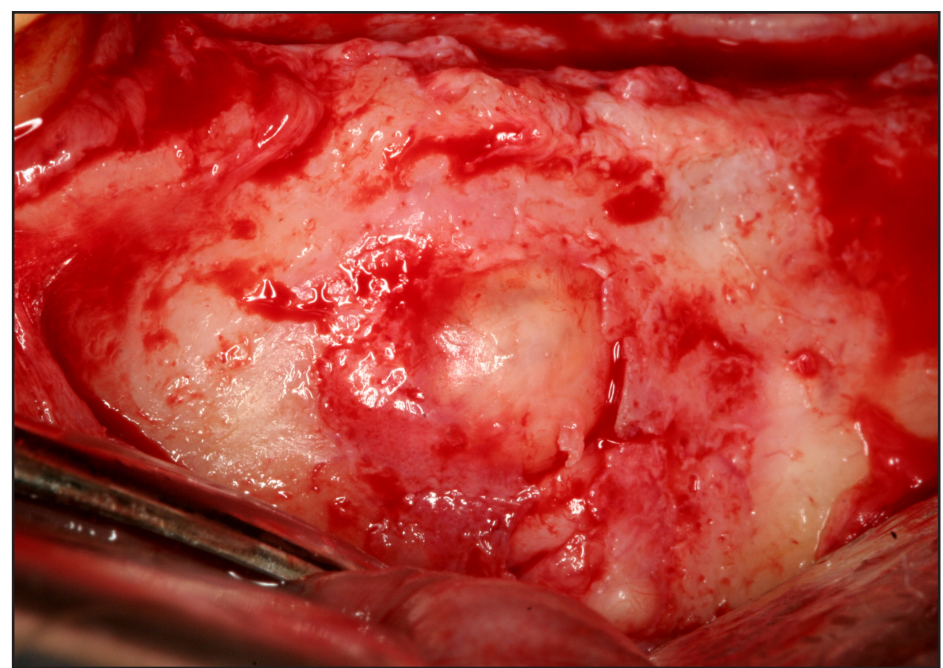

Figure 3. Photograph demonstrating intraoperative findings of destruction of the buccal cortical plate of the mandible.

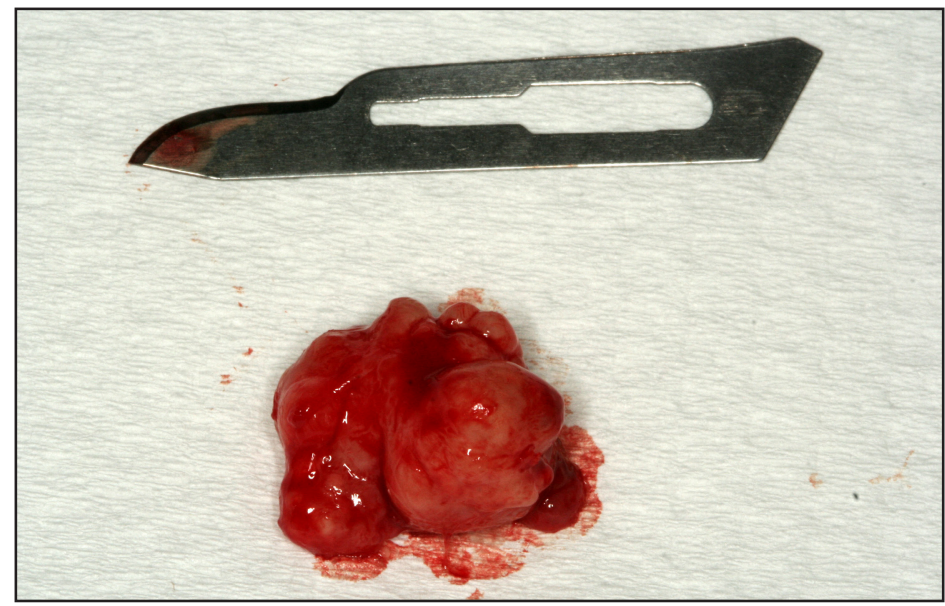

Figure 4. Photograph of surgical specimen appearing as a lobulated soft tissue mass.
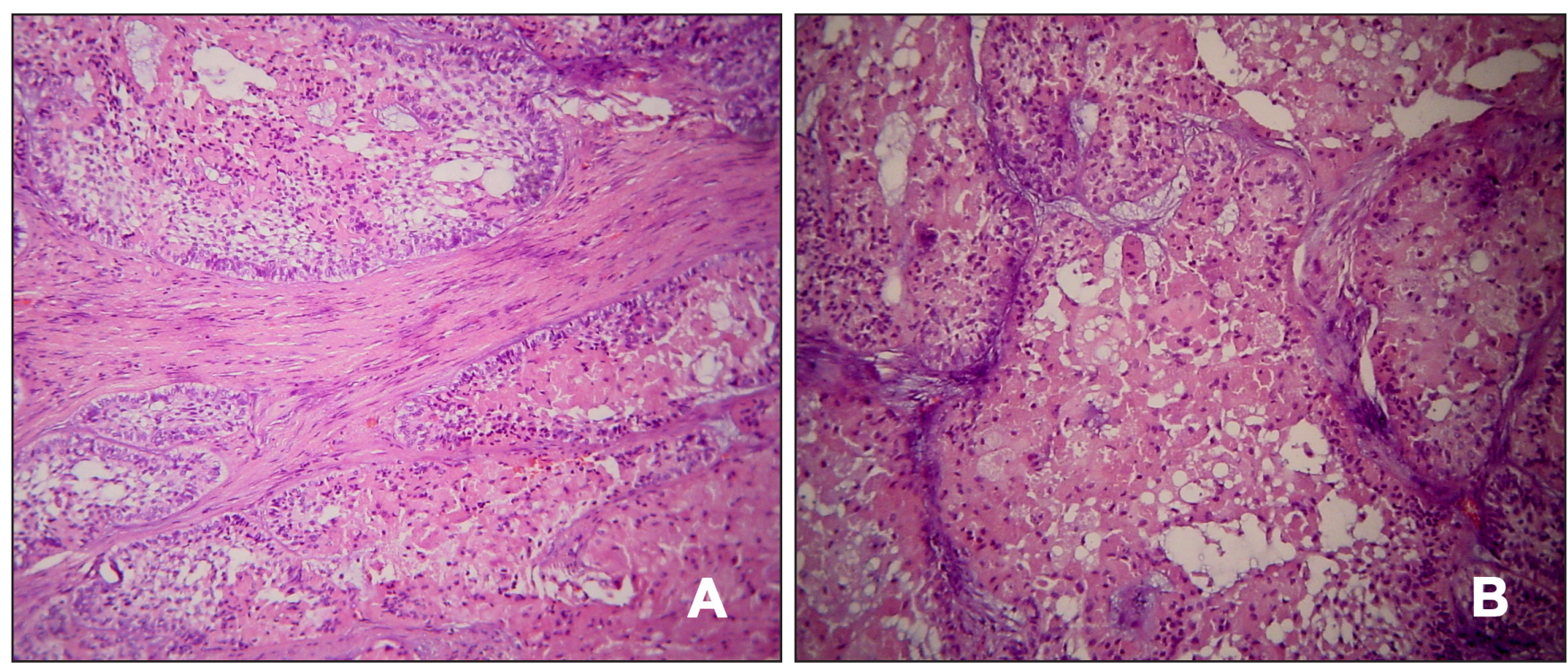

Figure 5. Photomicrographs showing tumour islands with a peripheral layer of ameloblassts and extensive central areas of granular cells with large, eosinophilic cytoplasmic granules.

$\mathrm{A}=$ hematoxylin and eosin stain, original magnification $\mathrm{x} 100$.

$\mathrm{B}=$ hematoxylin and eosin stain, original magnification $\mathrm{x} 200$. 


\section{DISCUSSION}

Granular cell ameloblastoma is a rare variant of ameloblastoma. In the clinicopathologic study of Kameyama et al. [6], only 1 out of 77 ameloblastoma cases was classified as the granular cell subtype. Reichart et al. [7] reviewed all available literature on ameloblastoma of the jaws from 1960 to 1993 and reported that out of a total of 1593 cases with available data on histologic subtypes, there were only $56(3.5 \%)$ cases of the granular cell variant. Its age distribution is considered to be quite similar to the other types of ameloblastomas, for which an average median age of 35 years old, ranging from 4 to 92 years, is reported [7]. Hartman [8] reviewed 20 cases of the granular cell ameloblastoma from the files of Armed Forces Institute of Pathology and reported an average age of 40.7 years (age range 21 - 65 years). Interestingly, $40 \%$ of the cases occurred in non-Caucasians, while there was no distinct gender predilection [8]. All tumours occurred in the mandible, the vast majority of which (19 out of 20) affected the posterior regions [ $\underline{8}$ ]; subsequent reviews confirmed the strong propensity for involvement of the mandible [9]. Jaw swelling and pain were the most frequent presenting symptoms. Compared to the other ameloblastoma subtypes, no distinguishing radiographic findings have been reported.

The biological behavior of granular cell ameloblastoma does not seem to differ from the other histologic subtypes of ameloblastoma; it can be locally aggressive and has a relatively high chance of recurrence [10]. Reichart et al. [7] reported a 33.3\% recurrence rate for granular cell ameloblastoma, which was higher, compared to the more common follicular, plexiform and acanthomatous subtypes. In Hartman's study [ 8$]$ ], 11 of 15 patients (73\%) developed recurrent lesions. However, similar to the other types of solid or multicystic ameloblastoma, the prognosis is more dependent on the method of surgical treatment, i.e. granular cell ameloblastomas treated by enucleation or curettage exhibit a high recurrence rate due to the fact that the border of the tumour within cancellous bone lies beyond the apparent macroscopic surface and the radiographic boundaries of the lesion. Therefore radical surgical methods are recommended [10]. Noteworthy is that granular cell ameloblastomas may rarely behave in a malignant fashion giving rise to metastasis [9].

Granular cell ameloblastoma is diagnosed by the presence of granular cells, which typically occur within the central area of tumour and progressively replace the stellate reticulum. Originally they were considered to represent an aging or degenerative process $[\underline{11}, \underline{12}]$, but recent immunohistochemical studies suggest that this phenomenon is related with increased apoptotic cell death of the lesional cells and the phagocytosis by neighbouring neoplastic cells [13]. Immunohistochemical investigation proved that the granular cells are positive for cytokeratin, CD68, lysozyme and alpha-1-antichymotrypsin, but negative for vimentin, desmin, S-100 protein, neuron-specific enolase and CD15, indicating epithelial origin and lysosomal aggregation [13]. Dina et al. [14] also showed that the granular cells exhibited membranous positivity for cytokeratin and cytoplasmic positivity for CD68.

The differential diagnosis of granular cell ameloblastomas includes other oral lesions with a similar morphology of granular cell accumulation, including granular cell odontogenic tumour, granular cell tumour and congenital epulis. These lesions have different biologic behavior and should be discriminated from granular cell ameloblastomas [15].

The granular cell odontogenic tumour is a type of odontogenic tumour featuring a proliferation of large cells with eosinophilic granular cytoplasm, which appear similar to the cells of granular cell ameloblastoma. They are very rare lesions which have been reported in patients of a wide age range with a female predilection [1]. Radiographically, they appear as multilocular or unilocular radiolucent lesions with occasional radiopacities [1]. In contrast to granular cell ameloblastoma, the granular cells of granular cell odontogenic tumour are not located within epithelial islands but constitute part of the tumour stroma. Small islands or cords of the odontogenic epithelium may be seen interspersed among the granular cells, while small cementum-like deposits and dystrophic calcifications are often found within the lesion $[\underline{1}, 16]$. Ultrastructurally, the granular cells are consistent with lysosomes, and are immunohistochemically positive for vimentin, CD68, muramidase, bcl-2, and negative for cytokeratin and S-100 protein [17]. The tumour is usually treated with enucleation and vigorous curettage, rarely recurs and its prognosis is very good.

The granular cell tumour is an uncommon benign soft tissue neoplasm that shows predilection for the oral cavity. The most common site is the tongue, followed by the buccal mucosa [18]. Differential diagnosis from a granular cell ameloblastoma is necessary when there is peripheral localization or cortical perforation and soft tissue extension of the ameloblastoma. Granular cell tumour usually occurs in the fourth to sixth decades of life and shows a female predilection. Clinically, it appears as an asymptomatic sessile nodule of small size [18]. Microscopic examination reveals large polygonal cells with abundant, pale, eosinophilic granular cytoplasm, with a small vesicular nucleus, arranged into sheets or nests $[\underline{18}, \underline{19}]$. Immonohistochemical 
investigation is positive for $\mathrm{S}-100$ protein, which could indicate neural origin. The occasional presence of pseudoepitheliomatous hyperplasia of the overlying epithelium, which can result in misdiagnosis of squamous cell carcinoma, is noteworthy $[\underline{18}, \underline{19}]$. The granular cell tumour is treated with conservative local excision and recurrence is uncommon.

Congenital epulis is an uncommon soft tissue tumour which occurs almost exclusively on the alveolar ridges of newborns or rarely on the tongue. Although this lesion is also composed of granular cells, the necessity of distinction from a granular cell ameloblastoma appears unlikely, considering occurrence of the latter in patients of older age. Interestingly, immunohistochemical investigation is negative for S-100 protein. The lesion is treated with conservative excision and there have been no reports of the recurrence. Additionally, it appears to stop growing after birth and may even diminish in size [18].

In recent years, research efforts have attempted to elucidate the molecular factors that govern the pathogenesis and progression of ameloblastoma and its subtypes by regulating critical cell processes, such as cell proliferation, apoptosis and differentiation. Numerous signaling pathways and molecules have been investigated including integrins [20], bone morphogenetic proteins (BMPs) [21], telomerase [22], angiogenic factors [23], matrix metalloproteinases [24], and apoptosis regulators $[\underline{25}, \underline{26}]$. More specifically, Kumamoto et al. [27] studied the role of p53-MDM2p14ARF cell cycle regulation system, and the rat sarcoma (Ras)/mitogen-activated protein kinase (MAPK) signalling pathway [28], in the oncogenesis and cytodifferentiation of odontogenic tumours, including ameloblastomas. Although the molecular components of the aforementioned systems were found to be expressed in a normal and neoplastic tissues, the granular cells of all studied granular cell ameloblastomas showed reduced or no activity. The same investigators explored the role of the p53 homologs (p63, p73) in odontogenic tumour development and reported significantly lower p63 and p73 expression levels in granular cell ameloblastomas compared to other tumour subtypes [29].

An investigation of the role of the mitochondriamediated apoptosis signaling pathway showed decrease or loss of immunoreactivity for the APAF-1 (apoptotic protease-activating factor-1), caspase-9 and AIF (apoptosis-inducing factor) in the granular cells of granular cell ameloblastomas [26]. Also, Luo et al. [25] evaluated the expression patterns of apoptosisrelated proteins, including Fas, Fas-ligand (FasL), caspase-3 and Bcl-2, in various cellular components of ameloblastomas; in granular cell ameloblastomas, strong or moderate expression of Fas antigen, weakly positive expression of FasL and caspase-3, and no expression of Bcl-2 were found. Moreover, Kumamoto et al. [30] studied the immunochemical expression of the apoptosis-related molecules Bid, Bim, Bad, Noxa and Puma (BH3-only proteins) in tooth germs, ameloblastomas and ameloblastic tumours, indicating their expression in the odontogenic epithelial cells near the basement membrane in tooth germs and ameloblastic tumours. Interestingly, the granular cells in granular cell ameloblastomas showed immunoreactivity for these BH3-only proteins, while other subtypes like acanthomatous ameloblastomas showed no reactivity, suggesting a possible additional role of these proteins in tumour cell differentiation [30].

As far as the role of angiogenic factors in the development and progression of odontogenic tumours is concerned, Kumamoto et al. [23] have reported that the expression of platelet-derived endothelial cell growth factor/thymidine phosphorylase (PD-ECGF/TP) was significantly higher in ameloblastomas than tooth germs. Immunoreactivity for angiopoietin- 1 and -2 was detected predominantly in the odontogenic epithelial cells near the basement membrane, in both normal and neoplastic tissues. Granular cell ameloblastomas showed PD-ECGF/TP reactivity in granular neoplastic cells as well as in stromal cells [23]

It has been proposed that BMPs and their associated molecules may regulate the cytodifferentiation of normal and neoplastic odontogenic epithelium via epithelialmesenchymal interactions [21]. Sathi et al. [31] focused on the role of BMPs and the Wnt signaling pathway molecules in granular cell ameloblastomas. Strong expression of the $\beta$-catenin and Wnt-5a was identified within the granular cells of all studied samples, while BMP-4 expression was weak and Wnt-2 was negative, suggesting abnormalities in synthesis and secretion of signaling molecules.

The possible contribution of novel signaling pathways such as Notch, sonic hedgehog ( $\mathrm{SHH}$ ) and PI3K/Akt/ mTOR in the pathogenesis of ameloblastomas has recently been in the center of attention. Kumamoto et al. [32] analyzed the expression of Notch receptors and ligands in ameloblastomas and tooth germs; mRNA expression of Notch1, Notch2, Notch3, Denta1 and Jagged1 was identified in all samples of normal and neoplastic odontogenic tissues, but not in keratinizing cells or granular cells in the corresponding ameloblastoma variants. The detection of mRNA and protein expression of $\mathrm{SHH}, \mathrm{PTCH}, \mathrm{SMO}$, and Gli1 in the ameloblastomas suggests these $\mathrm{SHH}$ signaling molecules may play a role in epithelial-mesenchymal interactions and cell proliferation during growth of these tumours [33-35]. Also, a number of studies have revealed aberrant signaling in the $\mathrm{PI} 3 \mathrm{~K} / \mathrm{AKT} / \mathrm{mTOR}$ 
pathway in ameloblastomas [36-38]. Scheper et al. [39] have shown that PTEN was completely absent in $33.3 \%$ of ameloblastomas, while the active, stabilized, phosphorylated form was lacking in $83.3 \%$ of cases. In addition, Akt was upregulated in the majority (83.3\%) of ameloblastomas, with overexpression of the p-thr Akt and p-ser Akt seen in $93.3 \%$ and $56.6 \%$ of cases, respectively. Finally, pS6K, a downstream target of mTOR, was shown to be upregulated in $86.7 \%$ of ameloblastomas with a positive correlation with AKT upregulation [39]. It is hoped that the evolving understanding of the altered pathways in ameloblastoma may soon provide non-surgical options for treatment of this condition [눙.

\section{CONCLUSIONS}

The granular cell ameloblastoma is a rare condition with unique histopathologic and immunohistochemical findings; its treatment and prognosis do not significantly differ from those of the other subtypes of the solid/ multicystic ameloblastoma. However, it should be differentiated from the other granular cell lesions primarily because of its higher recurrence rate. A better understanding of the molecular pathogenesis of ameloblastoma and its subtypes is under way and may provide diagnostic and therapeutic benefits.

\section{ACKNOWLEDGMENTS AND DISCLOSURE STATEMENTS}

The authors report no conflicts of interest related to this study. There was no external source of funding for the study.

\section{REFERENCES}

1. Neville BW, Damm DD, Allen CM, Bouquot JE. Odontogenic cysts and tumours. In: Neville BW, Damm DD, Allen CM, Bouquot JE, editors. Oral and Maxillofacial Pathology. 3rd ed. St. Louis: Saunders; 2009. p. 702-11, 729.

2. Snead ML, Luo W, Hsu DD, Melrose RJ, Lau EC, Stenman G. Human ameloblastoma tumors express the amelogenin gene. Oral Surg Oral Med Oral Pathol. 1992 Jul;74(1):64-72. [Medline: 1508512] [doi: 10.1016/0030-4220(92)90217-E]

3. Kumamoto H, Yoshida M, Ooya K. Immunohistochemical detection of amelogenin and cytokeratin 19 in epithelial odontogenic tumors. Oral Dis. 2001 May;7(3):171-6. [Medline: 11495193] [doi: 10.1034/j.1601-0825.2001.70306.x]

4. Ord RA, Blanchaert RH Jr, Nikitakis NG, Sauk JJ. Ameloblastoma in children. J Oral Maxillofac Surg. 2002 Jul;60(7):76270; discussion, 770-1. Review. [Medline: 12089689] [doi: 10.1053/joms.2002.33242]

5. Regezi JA, Sciubba JJ, Jordan RCK. In: Oral pathology: Clinical pathologic correlations. 4th ed. St. Louis, Missouri: WB. Saunders; 2003. p. 267-274.

6. Kameyama Y, Takehana S, Mizohata M, Nonobe K, Hara M, Kawai T, Fukaya M. A clinicopathological study of ameloblastomas. Int J Oral Maxillofac Surg. 1987 Dec;16(6):706-12. Review. [Medline: 3125270] [doi: 10.1016/S0901-5027(87)80057-7]

7. Reichart PA, Philipsen HP, Sonner S. Ameloblastoma: biological profile of 3677 cases. Eur J Cancer B Oral Oncol. 1995 Mar;31B(2):86-99. Review. [Medline: 7633291] [doi: 10.1016/0964-1955(94)00037-5]

8. Hartman KS. Granular-cell ameloblastoma. Oral Surg Oral Med Oral Pathol. 1974 Aug;38(2):241-53. [Medline: 4528580] [doi: 10.1016/0030-4220(74)90063-2]

9. Takahashi K, Kitajima T, Lee M, Iwasaki N, Inoue S, Matsui N, Ohki K, Nagao K, Akikusa B, Matsuzaki O. Granular cell ameloblastoma of the mandible with metastasis to the third thoracic vertebra. A case report. Clin Orthop Relat Res. 1985 Jul-Aug;(197):171-80. [Medline: 4017332] [doi: 10.1097/00003086-198507000-00021]

10. Ghandhi D, Ayoub AF, Pogrel MA, MacDonald G, Brocklebank LM, Moos KF. Ameloblastoma: a surgeon's dilemma. J Oral Maxillofac Surg. 2006 Jul;64(7):1010-4. [Medline: 16781332] [doi: 10.1016/j.joms.2006.03.022]

11. Nasu M, Takagi M, Yamamoto H. Ultrastructural and histochemical studies of granular-cell ameloblastoma. J Oral Pathol. 1984 Aug;13(4):448-56. [Medline: 6432988] [doi: 10.1111/j.1600-0714.1984.tb01445.x]

12. Tandler B, Rossi EP. Granular cell ameloblastoma: electron microscopic observations. J Oral Pathol. 1977 Nov;6(6):401-12. [Medline: 412933] [doi: 10.1111/j.1600-0714.1977.tb01807.x]

13. Kumamoto H, Ooya K. Immunohistochemical and ultrastructural investigation of apoptotic cell death in granular cell ameloblastoma. J Oral Pathol Med. 2001 Apr;30(4):245-50. [Medline: 11302245] [doi: $10.1034 / j .1600-0714.2001 .300409 . x$ ]

14. Dina R, Marchetti C, Vallania G, Corinaldesi G, Eusebi V. Granular cell ameloblastoma. An immunocytochemical study. Pathol Res Pract. 1996 Jun;192(6):541-6. [Medline: $\underline{\text { 8857640] }}$ 
15. Mirchandani R, Sciubba JJ, Mir R. Granular cell lesions of the jaws and oral cavity: a clinicopathologic, immunohistochemical, and ultrastructural study. J Oral Maxillofac Surg. 1989 Dec;47(12):1248-55. [Medline: 2479730] [doi: 10.1016/0278-2391(89)90718-0]

16. Meer S, Altini M, Coleman H, Daya N. Central granular cell odontogenic tumor: immunohistochemistry and ultrastructure. Am J Otolaryngol. 2004 Jan-Feb;25(1):73-8. [Medline: 15011210] [doi: 10.1016/j.amjoto.2003.09.002]

17. Slater L. Granular cell ameloblastoma versus central odontogenic granular cell tumor. Oral Oncol. 1997 Mar;33(2):145. [Medline: 9231174] [doi: 10.1016/S0964-1955(96)00051-6]

18. Neville BW, Damm DD, Allen CM, Bouquot JE. Soft tissue tumors. In: Oral and Maxillofacial Pathology. 3rd ed. St Louis, Mo: W.B. Saunders; 2009; 537-538.

19. Chrysomali E, Nikitakis NG, Tosios K, Sauk JJ, Papanicolaou SI. Immunohistochemical evaluation of cell proliferation antigen Ki-67 and apoptosis-related proteins Bcl-2 and caspase-3 in oral granular cell tumor. Oral Surg Oral Med Oral Pathol Oral Radiol Endod. 2003 Nov;96(5):566-72. [Medline: 14600691] [doi: 10.1016/S1079-2104(03)00371-8]

20. Souza Andrade ES, da Costa Miguel MC, Pinto LP, de Souza LB. Ameloblastoma and adenomatoid odontogenic tumor: the role of alpha2beta1, alpha3beta1, and alpha5beta1 integrins in local invasiveness and architectural characteristics. Ann Diagn Pathol. 2007 Jun;11(3):199-205. [Medline: 17498594] [doi: 10.1016/j.anndiagpath.2006.04.005]

21. Kumamoto H, Ooya K. Expression of bone morphogenetic proteins and their associated molecules in ameloblastomas and adenomatoid odontogenic tumors. Oral Dis. 2006 Mar;12(2):163-70. [Medline: 16476038] [doi: 10.1111/j.1601-0825.2005.01177.x]

22. Kumamoto H, Kinouchi Y, Ooya K. Telomerase activity and telomerase reverse transciptase (TERT) expression in ameloblastomas. J Oral Pathol Med. 2001 Apr;30(4):231-6. [Medline: 11302243] [doi: 10.1034/j.1600-0714.2001.300407.x]

23. Kumamoto H, Ooya K. Immunohistochemical detection of platelet-derived endothelial cell growth factor/ thymidine phosphorylase and angiopoietins in ameloblastic tumors. J Oral Pathol Med. 2006 Nov;35(10):606-12. [Medline: 17032393 ] [doi: $\underline{10.1111 / \mathrm{j} .1600-0714.2006 .00458 . x]}$

24. Wang A, Zhang B, Huang H, Zhang L, Zeng D, Tao Q, Wang J, Pan C. Suppression of local invasion of ameloblastoma by inhibition of matrix metalloproteinase-2 in vitro. BMC Cancer. 2008 Jun 30;8:182. [Medline: 18588710] [doi: 10.1186/1471-2407-8-182] [FREE Full Text]

25. Luo HY, Yu SF, Li TJ. Differential expression of apoptosis-related proteins in various cellular components of ameloblastomas. Int J Oral Maxillofac Surg. 2006 Aug;35(8):750-5. Epub 2006 May 9. [Medline: 16690252] [doi: 10.1016/j.ijom.2006.03.012]

26. Kumamoto H, Ooya K. Detection of mitochondria-mediated apoptosis signaling molecules in ameloblastomas. J Oral Pathol Med. 2005 Oct;34(9):565-72. [Medline: 16138896] [doi: 10.1111/j.1600-0714.2005.00354.x]

27. Kumamoto H, Izutsu T, Ohki K, Takahashi N, Ooya K. p53 gene status and expression of p53, MDM2, and p14 proteins in ameloblastomas. J Oral Pathol Med. 2004 May;33(5):292-9. [Medline: 15078490] [doi: 10.1111/j.0904-2512.2004.00044.x]

28. Kumamoto H, Takahashi N, Ooya K. K-Ras gene status and expression of Ras/mitogen-activated protein kinase (MAPK) signaling molecules in ameloblastomas. J Oral Pathol Med. 2004 Jul;33(6):360-7. [Medline: 15200485] [doi: 10.1111/j.1600-0714.2004.00141.x]

29. Kumamoto H, Ohki K, Ooya K. Expression of p63 and p73 in ameloblastomas. J Oral Pathol Med. 2005 Apr;34(4):220-6. [Medline: 15752257] [doi: 10.1111/j.1600-0714.2005.00284.x]

30. Kumamoto H, Ooya K. Immunohistochemical detection of BH3-only proteins in ameloblastic tumors. Oral Dis. 2008 Sep;14(6):550-5. [Medline: 18826384] [doi: 10.1111/j.1601-0825.2007.01417.x]

31. Sathi GS, Han PP, Tamamura R, Nagatsuka H, Hu H, Katase N, Nagai N. Immunolocalization of cell signaling molecules in the granular cell ameloblastoma. J Oral Pathol Med. 2007 Nov;36(10):609-14. [Medline: 17944754] [doi: $10.1111 / \mathrm{j} .1600-0714.2007 .00580 . \mathrm{x}]$

32. Kumamoto H, Ohki K. Detection of Notch signaling molecules in ameloblastomas. J Oral Pathol Med. 2008 Apr;37(4):22834. Epub 2008 Jan 19. [Medline: 18221321] [doi: 10.1111/j.1600-0714.2007.00629.x]

33. Kumamoto H, Ohki K, Ooya K. Expression of Sonic hedgehog (SHH) signaling molecules in ameloblastomas. J Oral Pathol Med. 2004 Mar;33(3):185-90. [Medline: 15128061] [doi: 10.1111/j.0904-2512.2004.00070.x]

34. Barreto DC, Bale AE, De Marco L, Gomez RS. Immunolocalization of PTCH protein in odontogenic cysts and tumors. J Dent Res. 2002 Nov;81(11):757-60. [Medline: 12407090] [doi: 10.1177/154405910208101107] [ [FREE Full Text]

35. Zhang L, Chen XM, Sun ZJ, Bian Z, Fan MW, Chen Z. Epithelial expression of SHH signaling pathway in odontogenic tumors. Oral Oncol. 2006 Apr;42(4):398-408. Epub 2005 Dec 22. [Medline: 16376138] [doi: 10.1016/j.oraloncology.2005.09.008]

36. Sandra F, Harada H, Nakamura N, Ohishi M. Midkine induced growth of ameloblastoma through MAPK and Akt pathways. Oral Oncol. 2004 Mar;40(3):274-80. [Medline: 14747058] [doi: 10.1016/j.oraloncology.2003.08.011]

37. Hendarmin L, Sandra F, Nakao Y, Ohishi M, Nakamura N. TNFalpha played a role in induction of Akt and MAPK signals in ameloblastoma. Oral Oncol. 2005 Apr;41(4):375-82. [Medline: 15792609] [doi: 10.1016/j.oraloncology.2004.09.014] 
38. Nodit L, Barnes L, Childers E, Finkelstein S, Swalsky P, Hunt J. Allelic loss of tumor suppressor genes in ameloblastic tumors. Mod Pathol. 2004 Sep;17(9):1062-7. [Medline: 15133474] [doi: 10.1038/modpathol.3800147]

39. Scheper MA, Chaisuparat R, Nikitakis NG, Sauk JJ. Expression and alterations of the PTEN/AKT / mTOR pathway in ameloblastomas. Oral Dis. 2008 Sep;14(6):561-8. [Medline: 18826385 ] [doi: 10.1111/j.1601-0825.2007.01421.x]

40. Sauk JJ, Nikitakis NG, Scheper MA. Are we on the brink of nonsurgical treatment for ameloblastoma? Oral Surg Oral Med Oral Pathol Oral Radiol Endod. 2010 Jul;110(1):68-78. Epub 2010 Apr 24. [Medline: 20418126] [doi: 10.1016/j.tripleo.2010.01.024]

\section{To cite this article:}

Nikitakis NG, Tzerbos F, Triantafyllou K, Papadimas C, Sklavounou A. Granular Cell Ameloblastoma: an Unusual Histological Subtype Report and Review of Literature.

J Oral Maxillofac Res 2010;1(4):e3

URL: http://www.ejomr.org/JOMR/archives/2010/4/e3/v1n4e3ht.pdf

doi: $10.5037 /$ jomr.2010.1403

Copyright (C) Nikitakis NG, Tzerbos F, Triantafyllou K, Papadimas C, Sklavounou A. Accepted for publication in the JOURNAL OF ORAL \& MAXILLOFACIAL RESEARCH (http://www.ejomr.org/), 29 September 2010.

This is an open-access article, first published in the JOURNAL OF ORAL \& MAXILLOFACIAL RESEARCH, distributed under the terms of the Creative Commons Attribution-Noncommercial-No Derivative Works 3.0 Unported License, which permits unrestricted non-commercial use, distribution, and reproduction in any medium, provided the original work and is properly cited. The copyright, license information and link to the original publication on (http://www.ejomr.org/) must be included. 